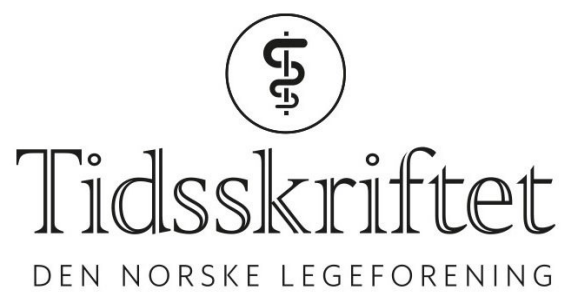

\title{
Smertebehandling ved kronisk kreftsykdom
}

KRONIKK

\section{OLAV MAGNUS S. FREDHEIM}

E-post: olav.m.fredheim@ntnu.no

Olav Magnus S. Fredheim er overlege ved Palliativt senter, Akershus universitetssykehus og professor i anestesiologi og smertemedisin ved NTNU.

Forfatteren har fylt ut ICMJE-skjemaet og oppgir ingen interessekonflikter.

\section{STEIN KAASA}

Stein Kaasa er avdelingsleder ved Avdeling for kreftbehandling, Oslo universitetssykehus, professor i onkologi/palliativ medisin ved Universitetet i Oslo og leder for European Palliative Care Research Centre.

Forfatteren har fylt ut ICMJE-skjemaet og oppgir ingen interessekonflikter.

\section{PETTER C. BORCHGREVINK}

Petter C. Borchgrevink er avdelingsleder ved Avdeling for smerte og sammensatte symptomlidelser, St. Olavs hospital, professor i anestesiologi og smertemedisin ved NTNU og leder for Nasjonal kompetansetjeneste for sammensatte symptomlidelser.

Forfatteren har fylt ut ICMJE-skjemaet og oppgir ingen interessekonflikter.

Stadig flere lever lenge med stabil kreftsykdom. Mange av disse pasientene vil ha moderate til sterke smerter. Dersom det anvendes feil prinsipper for smertebehandlingen, kan det føre til alvorlige bivirkninger.

Fremskritt i den onkologiske behandlingen endrer situasjonen for store grupper av kreftpasienter. Flere vil leve i mange år med en kreftsykdom (1). Disse pasientene skiller seg tydelig både fra pasienter med kurert kreftsykdom og fra pasienter med langtkommen sykdom med kort forventet levetid.

Tradisjonelt har det vært et klart skille mellom smertebehandling av kreftsmerte og langvarig ikke-malign smerte (2). Hovedforskjellen er at ved langvarig ikke-malign smerte skal opioider bare brukes hos få og utvalgte pasienter, og behandling skal være rettet mer mot bedring av funksjon enn mot smertelindring (3). Ved kreftsmerte anbefales derimot opioidbehandling hvis paracetamol eller lignende medikamenter ikke gir effektiv smertelindring (4). Det er godt dokumentert at mange kreftpasienter ikke får god nok smertebehandling (5), blant annet fordi man begynner med opioider for sent $\mathrm{i}$ sykdomsforløpet og ofte i for lave doser. Det er viktig å arbeide nasjonalt og internasjonalt for å gi pasienter med kort forventet levetid god tilgang på opioider.

I Norge har vi vært svært tilbakeholdne med opioidbehandling ved langvarig ikke-malign smerte. Denne restriktive linjen har nok vært en viktig grunn til at vi ikke har fått en 
tilsvarende «epidemi» med avhengighetssyndrom og dødsfall som i USA (6). Pasienter som har blitt friske etter kreftsykdom og får smerter etter avsluttet kurativ behandling, skal behandles på samme måte som pasienter med langvarig ikke-malign smerte, der man $\emptyset$ nsker å unngå opioider og ha vekt på mestringsorientert oppfølging $(7,8)$.

For den økende gruppen av kreftpasienter som lever med stabil kreftsykdom med lav tumorbyrde i mange år, bør etter vårt syn bruken av opioider i stor grad være basert på de samme restriktive prinsippene som for pasienter med langvarig ikke-malign smerte.

\section{Hvilken smerte blir behandlet?}

Jo lenger kreftpasienter skal leve med sin kreftsykdom, jo viktigere vil det være å gi riktig klassifisering av smertetilstanden (tabell 1). Ikke all smerte hos en kreftpasient er kreftsmerte eller skal behandles som kreftsmerte. Behovet for diagnostikk og klassifisering av smerte hos kreftpasientene har ført til at det nye diagnosesystemet ICD-11 inneholder en omfattende klassifikasjon av langvarig kreftrelatert smerte der man skiller mellom smerter fra tumormassene, smerte som følge av onkologisk eller kirurgisk behandling og smerte som ikke er relatert til kreftsykdommen (9). Hos kreftpasienter gjelder de samme prinsippene både for behandling av akutt smerte og langvarig ikke-malign smerte som hos andre pasienter. Selv om kreftsmerte ofte lindres effektivt av opioider, er det viktig å huske at opioider ikke er mer effektive mot langvarig ikke-malign smerte hos kreftpasienter enn hos andre.

\section{Tabell 1}

Ulike typer smerte hos kreftpasienten. Diagnosekoder fra ICD-11 i parentes.

\begin{tabular}{|l|l|}
\hline Klassifisering av smerte etter ICD-11 & \\
\hline Tumorsmerte (MG30.10) & \multirow{2}{*}{ Hovedkategori av smerte } \\
\hline Smerte på grunn av kreftbehandling & \\
\hline Postoperativt ved kirurgi (MG31.2) & \\
\hline I forbindelse med strålebehandling (MG31.Y) & \\
\hline I forbindelse med kjemoterapi (MG31.Y) & \\
\hline Smerte som ikke er relatert til kreftsykdommen & \multirow{2}{*}{ Langvarig ikke-malign smerte } \\
\hline Akutt smerte & \\
\hline Smerte som ikke er relatert til kreftsykdommen & \\
\hline Langvarig ikke-malign smerte & \\
\hline Sekvele etter behandling & \\
\hline Nevropati etter kjemoterapi (MG30.11/MG30.51) & \\
\hline Stråleskade (MG30.11) & \\
\hline Kronisk postoperativ smerte (MG30.21) &
\end{tabular}

${ }^{1}$ Kan enten være i gruppen MG31 eller mer spesifikke akutte smertetilstander som finnes i andre avsnitt, slik som akutte rygg- eller brystsmerter

${ }^{2}$ Kan enten være i gruppen MGzo eller spesifikke diagnoser i andre avsnitt, slik som smerter fra artrose

\section{Bivirkninger ved langtidsbruk av opioider}

Bivirkninger som kan tolereres i en situasjon med progredierende kreftsykdom og kort forventet levetid, vil ofte være uakseptable for kreftpasienter med lang forventet levetid. I tillegg til de velkjente bivirkningene ved korttidsbruk gir langtidsbruk av opioider immunsuppresjon, vektøkning, hyperalgesi, hypogonadisme med redusert seksuell lyst og redusert fertilitet, osteoporose og lavere respons på adrenokortikotropt hormon (ACTH) (10). 
Denne restriktive linjen har nok vært en viktig grunn til at vi ikke har fått en tilsvarende 'epidemi' med avhengighetssyndrom og dødsfall som i USA

I tillegg kommer risikoen for problematisk opioidbruk eller avhengighetssyndrom. Risikoen for avhengighetssyndrom, som i verste fall kan medføre død, har blitt svært tydelig gjennom «opioidepidemien» som har tatt titusenvis av liv i USA de siste årene (6). Denne skyldes først og fremst en kombinasjon av aggressiv og uansvarlig markedsføring av opioider, undervurdering av avhengighetspotensialet og en tanke om at alle pasienter med sterke smerter "fortjener» å forsøke de mest potente smertestillende legemidlene uavhengig av diagnose/patofysiologi (11). Det siste argumentet kan tilsynelatende være i tråd med både velgjørenhetsprinsippet og rettferdighetsprinsippet innenfor medisinsk etikk, men konsekvensen har blitt dramatiske skadevirkninger.

\section{Prinsipper for bruk av opioider}

Bruken av opioider hos kreftpasienter med stabil sykdom, lav eller moderat tumorbyrde og stor sannsynlighet for flere års overlevelse, bør etter vår mening i stor grad være basert på de restriktive prinsippene for bruk av opioider ved langvarig ikke-malign smerte (ramme 1). Det viktigste tiltaket for å redusere og forebygge smerte, er å behandle den/de grunnleggende årsakene til smerten med tumorrettet behandling i form av stråling eller medikamenter.

\section{Ramme 1 Forfatternes forslag til prinsipper for bruk av opioider hos kreftpasienter med lang forventet levetid.}

Fokus bør være på aktivitet og mestring, ikke på medikamenter og smerteintensitet Jo mindre tydelig sammenhengen er mellom smerten og tumormasser, jo mer restriktiv bør man være med opioider

Langvarig smerte etter kirurgi, stråling eller kjemoterapi vil vanligvis være nevropatisk med liten forventet effekt av opioider

Ikke-opioider inkludert gabapentinoider/trisykliske antidepressiver bør utnyttes

Terskelen for moderat dose opioid i depotformulering ved tumorsmerte bør være forholdsvis lav

Terskelen for å trappe opp til høye doser opioider eller kombinere depotformuleringer med hurtigvirkende opioider bør være høy

Subkutan/intravenøs/intratekal administrasjon av opioider er ikke indisert ved stabil sykdom, lav/moderat tumormasse og mange års forventet levetid

Opioider med benzodiazepiner eller benzodiazepinlignende sovemedisiner skal ikke kombineres

Hovedprinsippet for den medikamentelle smertebehandlingen bør være at man skal være tilbakeholden med opioider, og, om det allikevel anses indisert, basere opioidbruk enten på en lav døgnkontinuerlig dose med en depotformulering eller en sporadisk ved behov-bruk, samt å unngå tilleggsmedisinering med benzodiazepiner og/eller benzodiazepinlignende sovemedisiner.

Det vil være større grunn til å forsøke opioider dersom pasientens smerteplager har en lokalisasjon som passer med tumormassene enn ved mer utbredte smerter som samsvarer dårlig med tumormassene. I motsetning til ved avansert kreftsykdom med kort forventet levetid, bør man etter vår mening ikke kombinere flere formuleringer av opioider. Vi mener også at intravenøs, subkutan eller intratekal administrasjon av opioider ikke er indisert ved lang forventet levetid. 


\section{Ikke-medikamentell tilnærming}

Mens fokuset ved kort forventet levetid rettes mot smerteintensitet og medikamenter, må det ved lang levetid fokuseres på funksjon og mestring. Dette er en grunnleggende forskjell som innebærer en helt annen tilnærming. Mens vi hos pasienten med langtkommen sykdom snakker mye om smerteintensitet og oppfordrer til bruk av hurtigvirkende opioider ved behov, bør fokus hos pasienten med lang forventet levetid være hvordan vedkommende skal greie å opprettholde nødvendige daglige gjøremål og lystbetonte aktiviteter til tross for smerte. Det innebærer at smertetopper mestres med ikkemedikamentelle strategier, blant annet basert på at pasienten minner seg selv om at smertetopper er velkjente, vil gå over, ikke er uttrykk for noe farlig og at aktivitet kan opprettholdes selv om smerten svinger.

\section{Dynamisk tilnærming}

Noen av pasientene som lever lenge med kreft, vil ha store tumormasser og sterke smerter ved diagnosetidspunktet, og noen kan ha sterke akutte smerter i forbindelse med den tumorrettede behandlingen tidlig i forløpet. Ved diagnosetidspunktet vet man heller ikke hvilke pasienter som kommer til å respondere på den tumorrettede behandlingen og leve lenge med lav eller moderat tumorbyrde, og hvem som ikke responderer på behandling. Hos en del pasienter vil det i en periode tidlig i sykdomsforløpet være indisert med en liberal bruk av opioider, på samme måte som ved langtkommen kreftsykdom eller akutt smerte. Når pasientene responderer på den tumorrettede behandlingen og både tumormasser og smerter avtar, er vår sterke anbefaling at opioidbruken endres fra den liberale til den restriktive linjen som er beskrevet ovenfor. Det overordnete målet bør være å avslutte bruk av opioider.

\section{Tidlig palliasjon i onkologien}

Det er klart dokumentert i kliniske studier at det er nyttig for kreftpasienter at den palliativmedisinske helhetlige tilnærmingen med fokus på symptomer og livskvalitet anvendes allerede tidig i sykdomsforløpet (12). I utredningen På liv og død anbefales det derfor at man integrerer det pasientsentrerte palliative fokuset inn i helsetjenesten (13). Kreftpasienter som lever lenge vil ha nytte av denne pasientsentrerte tilnærmingen. Imidlertid er det avgjørende å ikke forveksle den palliativmedisinske helhetlige tilnærmingen tidlig i sykdomsforløpet med strategiene og teknikkene for smertebehandling som brukes ved langtkommen sykdom og ved livets slutt.

\section{Kompetanse og ansvarsplassering}

For å hjelpe pasientgruppen som omtales her, vil det være nødvendig med kunnskap både om kreftsykdommen, om den helhetlige palliative tilnærmingsmåten samt medikamentell og ikke-medikamentell mestringsorientert smertebehandling. Kreftavdelinger, smertepoliklinikker eller palliativt team/senter har per i dag kun unntaksvis all denne kompetansen. Det er behov for at hvert helseforetak bygger kompetanse og kapasitet for å behandle smerter hos denne pasientgruppen, som øker i størrelse. Lokale forhold bør avgjøre hvordan smertebehandlingen best kan organiseres. For å få det til må ansvar plasseres og ressurser tilføres. Hvis ikke risikerer vi at pasienter faller mellom flere stoler og ikke får riktig behandling. Feilbehandling med liberal bruk av opioider til denne pasientgruppen kan få alvorlige følger.

1. Cancer in Norway. 2017. Cancer incidence, mortality, survival and prevalence in Norway. Oslo: Kreftregisteret, 2018. https://www.kreftregisteret.no/globalassets/cancer-in-norway/2017/cin-2017.pdf Lest 11.6.2019. 
2. Ashburn MA, Staats PS. Management of chronic pain. Lancet 1999;353: 1865-9. [PubMed][CrossRef]

3. Ballantyne JC, Kalso E, Stannard C. WHO analgesic ladder: a good concept gone astray. BMJ 2016;352: i2o. [PubMed][CrossRef]

4. Caraceni A, Hanks G, Kaasa S et al. Use of opioid analgesics in the treatment of cancer pain: evidencebased recommendations from the EAPC. Lancet Oncol 2012; 13: e58-68. [PubMed][CrossRef]

5. Thronæs M, Raj SX, Brunelli C et al. Is it possible to detect an improvement in cancer pain management? A comparison of two Norwegian cross-sectional studies conducted 5 years apart. Support Care Cancer 2016; 24: 2565-74. [PubMed][CrossRef]

6. Ballantyne JC. Opioids for the treatment of chronic pain: Mistakes made, lessons learned, and future directions. Anesth Analg 2017; 125: 1769-78. [PubMed][CrossRef]

7. Paice JA, Portenoy R, Lacchetti C et al. Management of chronic pain in survivors of adult cancers: American Society of Clinical Oncology Clinical Practice Guideline. J Clin Oncol 2016;34:3325-45. [PubMed][CrossRef]

8. Glare PA, Davies PS, Finlay E et al. Pain in cancer survivors. J Clin Oncol 2014; 32: 1739-47. [PubMed][CrossRef]

9. Bennett MI, Kaasa S, Barke A et al. The IASP classification of chronic pain for ICD-11: chronic cancerrelated pain. Pain 2019;160:38-44. [PubMed][CrossRef]

10. Vuong C, Van Uum SH, O’Dell LE et al. The effects of opioids and opioid analogs on animal and human endocrine systems. Endocr Rev 2010;31: 98-132. [PubMed][CrossRef]

11. Van Zee A. The promotion and marketing of oxycontin: commercial triumph, public health tragedy. Am J Public Health 2009; 99: 221-7. [PubMed][CrossRef]

12. Kaasa S, Loge JH, Aapro M et al. Integration of oncology and palliative care: a Lancet Oncology Commission. Lancet Oncol 2018; 19: e588-653. [PubMed][CrossRef]

13. Norges offentlige utredninger. På liv og død - palliasjon til alvorlig syke og døende. NOU 2017:16. https://www.regjeringen.no/no/dokumenter/nou-2017-16/id2582548/sec1 Lest 17.3.2019.

Publisert: 23. september 2019. Tidsskr Nor Legeforen. DOI: 10.4045/tidsskr.19.0226

Mottatt 17.5.2019, første revisjon innsendt 3.6.2019, godkjent 11.6.2019.

(C) Tidsskrift for Den norske legeforening 2020. Lastet ned fra tidsskriftet.no 